\title{
CO-HOUSING ÉS VÁROSI FENNTARTHATÓSÁG
}

\author{
PIACI ÉS KÖZÖSSÉGI TÖBBLAKÁSOS FEJLESZTÉSEK \\ HELYVÁLASZTÁSA \\ A FENNTARTHATÓSÁG TÜKRÉBEN ${ }^{1}$
}

\author{
SZABÓ JULIANNA*四 KISSFAZEKAS KORNÉLIA** - BABOS ANNAMÁRIA*** \\ *PhD, okl. építészmérnök, egy. docens, BME Építészmérnöki Kar, Urbanisztika Tanszék, 1111 Budapest, \\ Mủegyetem rkp. 3. K II. 93. Tel.: (+36-1) 463-3847. E-mail: szabojuliannaphd@gmail.com \\ **PhD, okl. építészmérnök, tud. főmunkatárs, BME Építészmérnöki Kar, Urbanisztika Tanszék, \\ 1111 Budapest, Múegyetem rkp. 3. K II. 93. Tel.: (+36-1) 463-3847. E-mail: kissfazekas@urb.bme.hu, \\ kissfazekas@gmail.com \\ ***Okl. építészmérnök, PhD-hallgató, BME Építészmérnöki Kar, Urbanisztika Tanszék, 1111 Budapest, \\ Múegyetem rkp. 3. K II. 93. Tel.: (+36-1) 463-3847. E-mail: annamaria.babos@gmail.com
}

Nyugat-Európa városi lakásfejlesztéseiben az 1990-es évek óta megfigyelhető a környezeti fenntarthatósági szempontok, illetve a közösségi lakhatás szempontjainak terjedése. Egymáshoz közelító trendekről van szó, hiszen számos co-housing ${ }^{2}$ közösség alapértékként fogalmazza meg a fenntartható életmód kialakítását, ugyanakkor az integrált lakóközösség kialakítása és az azzal járó társadalmi előnyök a fenntarthatóság harmadik, társadalmi pillérének tekinthetők, ami egyre több zöld ingatlanminősítési rendszerben is megjelenik. Ugyanakkor a fejlesztés egyes döntéseiben a két trend által meghatározott szempontok nem mindig esnek egybe. Cikkünkben arra a kérdésre keressük a választ, hogy a városias többlakásos lakóingatlanok helykiválasztását milyen módon befolyásolhatja a környezettudatos és a co-housing szempontrendszer, felismerhetők-e karakteres különbségek, illetve miképpen és mely feltételekkel erősítheti egymást egy beruházásban a két nézőpont.

Elemzésünket Yosef Jabareen városi fenntarthatósági kritériumaira alapozzuk. A településföldrajzi lokációs elméletek analógiájára bevezetjük a telek helyi és helyzeti energiájának fogalmát. Jabareen kritériumait az ingatlanfejlesztés lokációs szempontjainak feleltetjük meg, szembeállítva egymással a tipikus piaci ingatlanfejlesztés szempontjait, a közösségi lakásépítés szempontrendszerével. Vizsgálatainkat részben a co-housing szakirodalom megállapításaira és esettanulmányaira, részben - széles körü és releváns magyar tapasztalatok hiányában - berlini megépült közösségi lakóházak adatbázisára építjük. Végezetül felvetjük a városi önkormányzati felelősség kérdését a közösségi lakásfejlesztések orientációjában, a fenntartható lokációs döntések támogatásában.

Kulcsszavak: fenntarthatóság, városi lakhatás, co-housing, helyválasztás, építőközösségek, lokáció, helyi és helyzeti energia

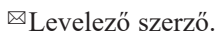

${ }^{1}$ A cikk az „E-CO-HOUSING - Több mint lakóház” projekt keretében készült. A projekt az Urban Innovative Action kezdeményezésre, az Európai Regionális Fejlesztési Alap társfinanszírozásában valósul meg.

${ }^{2}$ „Olyan lakhatási forma, ahol a lakók közös célok és érdekek mentén, a közösségi összefogás erejével fejlesztik lakhatási feltételeiket és lakókörnyezetüket. A lakók önkéntesen és tudatosan vállalják a közösséget egymással, az általuk meghatározott mértékben tereket, eszközöket, feladatokat, tevékenységeket osztanak meg egymással. A co-housingokat a nemzetközi szakirodalom hat ponttal definiálja, ezek különböztetik meg más lakhatási formáktól - például kollégiumoktól, lakóparkoktól, idősotthonoktól - melyekkel az elnevezés alapján könnyü összekeverni.” Babos-Horogh-Theiszler 2018. 69-76. 


\section{A VÁROS FENNTARTHATÓSÁGA}

A fenntartható fejlödés fogalmának megszületése ${ }^{3}$ után, az új évezred elején az elméleti irodalomban és a nemzetközi egyezmények szintjén is megjelent a városok felelőssége. ${ }^{4}$ A Rio+20-as konferencia 2012-ben megfogalmazta a fenntartható város célját $^{5}$, hiszen a városoknak - mint a gazdasági növekedés motorjainak, egyszersmind a fogyasztás központjainak - az együttmüködése nélkül elképzelhetetlen a világ fenntartható pályára állítása. A fenntartható város ettől a ponttól kezdve a környezeti diskurzus egyik alaptémájává vált. A nemzetközi politikák szintjén a témával foglalkozó források közül érdemes kiemelni a 2016-os New Urban Agendát ${ }^{6}$, az európai városokra megfogalmazott „Urban Agenda for the EU”-t ${ }^{7}$, illetve az ehhez kapcsolódó Amszterdami Megállapodást. Ezek a nemzetközi politikai egyezmények megfogalmazták azokat a követelményeket, amelyeket a fenntartható városoknak teljesíteniük kell, a befogadó lakhatástól az elérhető szociális szolgáltatásokon, zöld városi tereken, tiszta ivóvizen, egészséges levegőminőségen, tisztességes munkahelyeken és egyéb szempontokon keresztül egészen a hulladékok fenntartható kezeléséig. ${ }^{8}$

A fenntartható városforma tervezésének elvei és gyakorlata talán a legszerteágazóbb elméleti háttérrel rendelkezik az önkormányzati felelösségi körök közül, a tervezési koncepció és a fenntartható városforma közötti kapcsolat pedig ma a szakmai kutatások egyik fő vonulata. Mind a tudományos szakirodalom, mind a várostervezési gyakorlat több megközelítését ismeri a fenntartható város követelményeinek. Magyarországon a fenntartható városfejlesztés alapjait Szabó Árpád fejtette ki ${ }^{9}$, főbb szempontjai az optimális sürüség kialakítása, a meglévő struktúrák újrahasznosítása, a közterületek újraértelmezése a puha közlekedési módok elötérbe helyezésével, és a kék-zöld infrastruktúrák integrált fejlesztése volt. A nemzetközi szakirodalom legátfogóbb és legtöbbször hivatkozott rendszerezését Yosef Jabareen adta, aki 2006-os tanulmányában ${ }^{10}$ a szakirodalom széles körü feldolgozásával hat fö tervezési elvet fektetett le, aminek alapján négy nagy településrendezési koncepciót, szakmai áramlatot hasonlított össze. Annak ellenére, hogy számos más felosztás ismeretes, elemzésünkben az egyszerüség kedvéért Jabareen rendszerezését tekintjük kiindulópontnak, mert az átfogó forrásfeldolgozás alapján reálisan tükrözi a településtervezői

\footnotetext{
${ }^{3}$ Report of the World Commission on Environment and Development: Our Common Future. Oslo, 20 March 1987.

${ }^{4}$ Resolution adopted by the General Assembly on 27 July 2012 - 66/288. - The future we want.

${ }^{5}$ Report of the United Nations Conference on Environment and Development. Rio de Janeiro, 3-14 June 1992.

${ }^{6}$ The New Urban Agenda of United Nations Conference on Housing and Sustainable Urban Development (Habitat III) in Quito. Ecuador, on 20 October 2016.

${ }^{7}$ European Commission: New Urban Agenda for the EU.

${ }^{8}$ Urban Agenda for the EU - Pact of Amsterdam - 2016.

${ }^{9}$ Szabó Á. 2012. 91-105.

10 Jabareen 2006.
} 
szakma ma érvényes tudását, és saját szakmai elveinknek, tapasztalatainknak is megfelel. Munkája szerint a fenntartható várostervezés fö elvei:

1. a kompaktság

2. a fenntartható közlekedési rendszerek

3. a beépítés és a lakosság optimális sürüsége

4. a vegyes területfelhasználás

5. a funkciók, tevékenységek, formák, társadalmi csoportok változatossága

6. az éghajlati és benapozási viszonyok kihasználását lehetővé tévő Passive Solar Design

7. és az élő környezet integrálását biztosító Green Design

Bár számos kísérlet történt a városi fenntarthatóság mérésére ${ }^{11}$, Jabareen rendszerezésének széles körü elfogadottságát jelzi, hogy az UN Habitat ${ }^{12}$ ennek megfelelően számszerüsítette a fenntartható szomszédsági tervezés néhány alapelvét, mint a fenntartható közlekedési rendszereket, a városi sürüség minimumát, a vegyes területfelhasználás követelményét, vagy a társadalmi csoportok változatosságát. ${ }^{13,14}$

Jabareen áttekintése szerint a fenntartható tervezésre irányuló erőfeszítések négy szinten történtek: regionális vagy városkörnyéki léptékben, városi léptékben, szomszédsági léptékben, illetve az egyes épületek léptékében. Érvelése szerint a fenti elvek azért is általános érvényüek, mert érvényesek (érvényesíthetők) a tervezés minden szintjén, minden léptékében. Ugyanakkor a tervezési gyakorlat ma még nagyon eltérő fókuszú az egyes léptékek, elsősorban a várostervezés és az építészet fenntarthatósági szemlélete között. Összekapcsolásuk épp azon területen lehetséges és szükséges, ahol ma még csak részlegesen érvényesülnek a fenntarthatósági szempontok: a magán ingatlanfejlesztés területén.

\section{CO-HOUSING ÉS FENNTARTHATÓSÁG}

Tummers összefoglaló bibliografikus elemzése alapján a co-housingról szóló tematikus tanulmányok négy szempontból elemzik a témakört, az azt vizsgáló eltérő tudományterületnek megfelelően. ${ }^{15}$ Az építészeti megközelítésben az épületek tervezése, fizikai megvalósítása, szerkezeti és téri müködése kerül elemzésre. A társadalomtudományok területén a részvételt, a döntéshozási módokat, a kulturális sokszínüséget, a társadalmi változásokat vizsgálják a projektekben. Lakhatási és ingat-

\footnotetext{
${ }^{11}$ Szabó J. 2012.

${ }^{12} \mathrm{Az}$ UN-Habitat a városok jövőjével foglalkozó, ENSZ által biztosított program. Küldetésük népszerüsíteni a szociális és környezeti fenntarthatóság szerepét a települések fejlesztésénél, illetve a megfelelő lakóhely biztosításának fontosságát.

${ }^{13}$ A New Strategy of Sustainable Neighbourhood Planning: Five principle

http://mirror.unhabitat.org/pmss/listItemDetails.aspx?publicationID $=3518$

${ }^{14}$ Khoshnaw-Kissfazekas 2018.

${ }^{15}$ Tummers 2016. 40-46.
} 
lanfejlesztési szakemberek a jogi, finanszírozási és egyéb szervezeti hátteret kutatják, illetve a létrehozási és fenntartási folyamatokat elemzik. A várostervező és urbanista megközelítés a projektek elhelyezkedését, a szomszédsági környezet jellemzőit, a városszövetbe illeszkedését, a megközelíthetőségét és a helyszín adottságait és ellátottságát, a városi beavatkozás lehetőségét ${ }^{16}$ vizsgálják. Fenntarthatósági kritériumokat elsősorban az építészeti, társadalmi, illetve a co-housing jelenséget komplex nézőpontból elemző tanulmányok vizsgáltak.

Ma már széles körben elfogadott feltételezés, hogy a közösségi együttélés a modern társadalmak számos problémájára válaszolhat, beleértve az elidegenedést, a társadalmi elszigeteltséget és a fenntartható életet. A fenntarthatóság és közösségi együttélés összefüggései kapcsán Marckmann és kutatótársai ${ }^{17}$ négy fö szempontot nevesitettek, amelyek alapján a közösségi lakhatás fenntarthatóbb, mint a hétköznapi „társasházi” forma:

1. ezek a közösségek képesek és hajlandók fenntartható technológiák megvalósítására;

2. a közösségi lakóházak kisebb és kompaktabb épületek,

3. az épületek társadalmi összetétele megkönnyíti a lakók fenntartható életvitelének mindennapi gyakorlatát;

4. a közösségi együttlakás megoldást jelenthet a növekvő számú kis (egy- és kétszemélyes) háztartások környezeti kihívásaira, mely az egyike az új fenntarthatósági problémáknak.

Összegezve megállapították, hogy a környezetvédelmi fenntarthatóság szempontjából a co-housing épületek sürüsége és kompaktsága talán a legmeghatározóbb pozitívum.

A berlini Városfejlesztési Tanács (németül: Senatsverwaltung Stadtentwicklung) átfogó tanulmánya alapján ${ }^{18}$ az építőközösségeket tíz adottság jellemzi, amelyek közül számos emeli a co-housing fejlesztések fenntarthatóságát:

1. A szomszédsági és városi interakció, hiszen a közösségek magukénak érzik kisebb és nagyobb lakóhelyüket is, ezért folyamatosan fejlesztik azt.

2. A megosztott területek és közösségi programok azok, amelyek kulcsai ezen épületek hosszú távú fenntartásának és a szociálisan hátrányos csoportok segítésének.

3. A különleges fejlesztésnek köszönhetően az ingatlan bizonyos szempontból független a lakáspiac változásaitól, ezáltal hosszú távon megfizethetö, értékálló lakó- és munkaterületeket tartalmaz.

4. A befektetési lakóingatlanokkal szemben az építőközösségeknél fontos szempont, hogy a lakásokon felül nyitott és zöldfelületeket hozzanak létre a telken belül, melyeket gyakran a környék lakói is használhatnak.

\footnotetext{
${ }^{16}$ Krähmer-Kuhn 2009; Zulliger 2007; Ring 2015; Ring-Eidner 2013; Walljasper 2007.

${ }^{17}$ Marckmann et al. 2012. 413-416.

${ }^{18}$ Ring-Eidner 2013. 28-46.
} 
5. Új építésủ ingatlanok fejlesztése mellett elég gyakori a meglévő épületek átalakítása, bővítése az ilyen típusú fejlesztéseknél, ezáltal a leromlott területek újrahasznositása és aktiválása is jellemző.

6. A közösségek lakói nem csak lakhatási igényeiket szeretnék kielégíteni, így az ilyen típusú lakóházak úgynevezett „hibrid koncepció” mentén jönnek létre, különbözö funkciók keverésével.

7. A berlini lakhatás elmúlt 30 évének alakulása, illetve a fiatal pályakezdők és családosok igénye következtében a közösségek nagy része sủrübb városi szövetben keres magának helyet, a talált meglévő üres területet jó minőséggel süríti az új épülettel.

8. A felhasználóra szabott megoldások több generáció igényeit is kielégitik, ugyanis az ilyen épületek építészeti megoldásai általában rugalmasan módosíthatók, így képesek reagálni a lakók változó igényeire, illetve az esetleges későbbi lakócserékre is.

9. A berlini építőközösségek általában ökotudatosak, ezért ökológiailag tudatos épületbe fektetnek a lakók, annak tudatában is, hogy ezek a megoldások rövid távon költségesebbek.

10. Az építőközösségek nyitottabbak a kísérletezésre, mint a befektetők, így sok épületben különbözö kísérleti modelleket és megoldásokat alkalmaznak, melyekből a következő generációk lakásépítői tanulhatnak.

Winnie Yuen-Pik Chan diplomadolgozatában ${ }^{19}$ két piaci és három közösségi fejlesztésủ berlini többlakásos lakóépületet hasonlít össze részletes esettanulmányok alapján. Az esettanulmányok közölt adataiból látszik, hogy az építőközösségek által kezdeményezett és megvalósított lakóházak fejlesztése az ötlettől a beköltözésig általában hosszabb, mint a befektetöi fejlesztések. Az elemzett épületek esetében például a Kollwitz22 építöközösség létrehozási folyamata közel több mint 3 évig tartott, míg a befektetői alapú, közel azonos elhelyezkedésủ és méretü Kastaniengaerten 2 év alatt beköltözhetö lett. Ezzel összefügg, hogy a teljes építési költség is magasabb az építőközösségeknél, ami betudható az elhúzódó időtartamnak és az egyedi igényeknek egyaránt. Ezzel ellentétben a befektető olyan mértékü haszonnal dolgozik, hogy a lakások négyzetméter ára a közösségi fejlesztésnél számottevően alacsonyabb, 500-1000 euró árkülönbség is lehet négyzetméterenként.

A még olyan alaposan elemző tanulmányok is a fenntarthatóság megítélésében a közösségek fejlesztés és fenntartás folyamán meghozott döntéseit értékelik, mint az épületek funkcionális kevertségét, a külső használók számára biztosított funkciókat, az épületek energiatakarékos és ökologikus tervezését és kivitelezését, az aktív zöldfelületek létrehozását stb. ${ }^{20} \mathrm{~A}$ fenntartható fejlesztés azonban egy korábbi lépéssel kezdődik: a telek kiválasztásával, amely nagyban behatárolja a fejlesztés későbbi fenntartható alakítását. Tanulmányunkban erre a döntésre koncentrálunk.

${ }^{19}$ Chan 2010.

${ }^{20}$ Tummers 2017. 


\section{HELYI ÉS HELYZETI ENERGIA - A LOKÁCIÓ ÉRTÉKELÉSE A KOMPLEX VÁROSI KÖRNYEZETBEN}

Az ingatlanfejlesztés egyik első döntése a fejlesztendő ingatlan kiválasztása. A helykiválasztás pillanatában értelmezésünk szerint a település, mint egyfajta szolgáltatást, a fenntartható, illetve közösségi fejlesztést támogató környezetet nyújtó szereplö, a fejlesztő pedig mint ennek a környezetnek előnyeit-hátrányait értékelő fogyasztó kerülnek kapcsolatba egymással. Az adott telek kiválasztásával a fejlesztő a település fizikai, biológiai, gazdasági és társadalmi terében helyezi el a fejlesztését. Az adott telek jellemzőit így részben saját magát jellemző paraméterek, részben azonban a fent említett fizikai-társadalmi-gazdasági környezetben, a várost múködtető hálózatokban való elhelyezkedése határozza meg. A városok kialakulását magyarázó lokációs elméletek analógiájára a teleknek a városszerkezetbeli elhelyezkedéséböl adódó elönyeit a telek helyzeti energiájaként, míg a saját geometriájából adódó elönyeit a telek helyi energiájaként jellemezzük.

A telek helyzeti energiáját az definiálja, hogy hogyan helyezkedik el a város struktúrájában, miként tud kapcsolódni a várost müködtető hálózatokhoz, hogyan tudja ezeken keresztül kihasználni a térben távol eső városi erőforrásokat. A helyzeti energia összetevőit lépték szerint további két csoportra oszthatjuk: egyik csoportjukat az ingatlan közvetlen környezetének, szomszédságának, városrészének adottságai, a másik csoportot a teljes városi hálózatokban elfoglalt hely definiálja. Az első csoportba tartozó jellemző helyzeti energia például a városrész társadalmi státusza, felfelé vagy lefelé tartó dinamikája, amelyet az adott fejlesztés csak kis mértékben befolyásolhat. Hasonló helyzeti energia lehet a közvetlen környezet különleges természeti adottsága: a városi zöldfelületekhez, vízpartokhoz, légcsatornához való közelség. Idetartoznak a közvetlen környezetben elérhető - preferenciától függően értékelt oktatási, egészségügyi, kulturális, kereskedelmi, szolgáltatási intézmények is. (A helyzeti energiának természetesen lehetnek negatív összetevői is, mint például egy légifolyosó közelsége vagy az éppen itt kialakulóban lévő városi bulinegyed.) Az összvárosi hálózatokra való kapcsolódás helyzeti energiájára elsősorban a közlekedési hálózatok elérhetőségét, sebességét, kényelmét, alternatíváit, illetve a hálózaton belül elfoglalt helyzetet, a városközpont, repülötér vagy más fontos hely elérési idejét szoktuk példaként megemlíteni. Ugyanakkor éppen a fenntarthatósági szempontrendszerben elképzelhető más hálózati előny vagy hátrány is, mint például a távhőszolgáltatás vagy a nagy sebességü információs hálózatok elérhetősége.

A telek helyi energiájának legfontosabb alapja a geometriája - szélessége, mélysége, domborzata, a szomszédos ingatlanok beépítése vagy beépítési lehetősége. A piaci ingatlanfejlesztési gondolkodásmód a telek helyi energiáját elsősorban abból a szempontból értékeli, hogy a helyben hatályos építési szabályozás és a telek geometriája mennyi hasznos köbméter létrehozását teszi lehetővé. Ugyanakkor a geometria, a helyi klimatikus viszonyok és az építési szabályozás egymásra hatása talán még fontosabb abban a tekintetben, hogy a telken mennyire energiatakarékos, kör- 
nyezettudatos beépítés hozható létre. A tájolás, benapozás lehetőségei azt is behatárolják, hogy a telken milyen minőségi lakóterek és szabad terek hozhatók létre.

Egy adott telek helyi és helyzeti energiájának összessége természetesen nagyban függ a település tervezési, fejlesztési, szabályozási, szolgáltatási tevékenységétől. A fenntartható ingatlanfejlesztésre alkalmas telkek kialakítása így az önkormányzati felelősségek körébe is tartozik. A fenntartható településtervezés elmélete és a városi lokációk fenntarthatósági értékelésének gyakorlata azonban ma még nem találkoznak: ennek a két gondolkodásmódnak összevetésére teszünk kísérletet a piaci és a közösségi lakásfejlesztések általunk vázolt szempontrendszer szerinti elemzésével.

\section{A VÁROSI FENNTARTHATÓSÁG ELVÁRÁSAI A PIACI ÉS KÖZÖSSÉGI LAKÁSFEJLESZTÉSEK LOKÁCIÓS DÖNTÉSEI SORÁN}

Igen fontos kérdés, hogy miként fogalmazódnak meg egy adott telek kiválasztásánál a fenntarthatóság elvárásai. Egy tudatos, minden szempontból körültekinteni akaró előkészítő folyamat során milyen elvekre kell tekintettel lenni annak érdekében, hogy a megvalósult épület hosszabb távon is meg tudjon felelni a fenntarthatóság elvárásainak? Fontos leszögezni, hogy konkrét telek kiválasztását ma még erősebben motiválják más, a fenntarthatósághoz nem kapcsolódó tényezők; például a pénzügyi lehetőségek, a piac kínálata, a személyes kötődések a területhez stb. Feltételezve azonban azt az optimális állapotot, hogy telekválasztásnál a mérlegelés tárgyát képező szempontok sorába bekerül a hosszú távú fenntarthatóság kérdésköre is, vajon definiálhatók-e a választást befolyásoló speciális tényezők?

Az 1. táblázatban Jabareen fenntartható várostervezési elveinek feleltettük meg a városi többlakásos társasházak helykeresési szempontjait, keresve az egyezéseket, azonos irányba tartókat. Vajon miként érvényesülhetnek az általános városi léptékü „eszmék” konkrét fejlesztői döntések során? Látható, hogy a fenntartható város jellemzői a lokációs döntésekben részben a telek környezetének minőségeként, azaz helyzeti energiaként, részben pedig a telek saját minőségeként, azaz helyi energiaként jelennek meg. Jabareen elméletének megfelelően egyes elvek - mint például a Solar és a Green Design elvei - a város, a városrész, de a telek szintjén is érvényesíthetők, így a telekválasztásban helyzeti és helyi energiaként is értelmezhetők.

A kompaktság követelménye a város elterülése (angolul: urban sprawl) ellen fogalmazódott meg. Elsősorban a városkörnyéki zöldmezős családi házas parcellázások ellenében. A kilencvenes évek piaci társasházas fejlesztései sok esetben ennek ellentételeként jelentek meg, az irodalom az újból vonzó városi életmód jeleit látta meg bennük. Az ezredforduló után azonban, a szuburbánus területeken megjelentek a zöldmezőn, alacsony sürüségü társasházként fejlesztett lakóegyüttesek is. Jabareen a kompaktság követelményét úgy fogalmazza meg, hogy az új fejlesztésnek meglévő épület felhasználásával, átalakításával, konverziójával, bővítésével, esetleg bontásával kell létrejönnie; vagy az épülő ingatlannak a meglévő sürü városszövet hiátusá- 
1. táblázat. Jabareen fenntartható városfejlesztési elveinek megfelelő szempontok az ingatlanfejlesztés lokációs döntéseiben, azok helyi és helyzeti energiaként való értelmezése

\begin{tabular}{|c|c|c|c|}
\hline $\begin{array}{c}\text { Fenntartható várostervezési elvek } \\
\text { Jabareen szerint }\end{array}$ & $\begin{array}{c}\text { Telekválasztásban érvényesíthető szem- } \\
\text { pont }\end{array}$ & $\begin{array}{c}\text { Helyi } \\
\text { energia }\end{array}$ & $\begin{array}{l}\text { Helyzeti } \\
\text { energia }\end{array}$ \\
\hline a kompaktság & $\begin{array}{l}\text { konverzió vagy a meglévő } \\
\text { városszövet hiátusainak fejlesztése }\end{array}$ & $\mathrm{X}$ & \\
\hline a fenntartható közlekedési rendszerek & jó közösségi közlekedési ellátottság & & $\mathrm{X}$ \\
\hline $\begin{array}{l}\text { a beépítés és a lakosság optimális } \\
\text { sűrüsége }\end{array}$ & $\begin{array}{l}\text { városias beépítési formák } \\
\text { preferenciája }\end{array}$ & $\mathrm{X}$ & \\
\hline a vegyes területfelhasználás & zavaró környezeti hatások kerülése & & $\mathrm{X}$ \\
\hline $\begin{array}{l}\text { diverzitás: a funkciók, tevékenységek, } \\
\text { formák, társadalmi csoportok } \\
\text { változatossága }\end{array}$ & $\begin{array}{l}\text { gazdag városi szolgáltatások, } \\
\text { homogén társadalmi státuszú } \\
\text { csoport a lakóterületen }\end{array}$ & & $\mathrm{X}$ \\
\hline $\begin{array}{l}\text { az éghajlati és benapozási viszonyok } \\
\text { kihasználását lehetővé tévő Passive } \\
\text { Solar Design }\end{array}$ & $\begin{array}{l}\text { telek megfelelö tájolása, környező } \\
\text { épületek beépítése, aránya }\end{array}$ & $\mathrm{X}$ & $\mathrm{X}$ \\
\hline $\begin{array}{l}\text { az élő környezet integrálását biztosító } \\
\text { Green Design }\end{array}$ & $\begin{array}{l}\text { természeti környezet, zöldfelületi } \\
\text { elemek közelsége }\end{array}$ & $\mathrm{X}$ & $\mathrm{X}$ \\
\hline
\end{tabular}

ban épülnie, ahhoz legalább szervesen csatlakoznia. Mivel a foghíjtelkek általában az optimális fejlesztési volumennél kisebb építési lehetőséget biztosítanak, a meglévő épületek átalakítása és a konverzió pedig nagyobb fajlagos költségekkel járnak, a piaci lakásfejlesztés csak különleges igények (pl. loftlakások vagy belvárosi apartmanházak) esetén vagy állami / önkormányzati támogatás (pl. szennyezések mentesítése, közterületfejlesztés, lakáskiváltások támogatása stb.) segítségével céloz meg ilyen ingatlanokat. A fejlesztöi helykiválasztás így csak ritkán támogatja a kompaktság célját. A lakáskeresők szempontrendszerében azonban egyre erősebben megjelennek azok az igények - városias környezet és szolgáltatások, központ elérhetősége -, amelyek a kompaktságot áttételesen támogató igényeknek tekinthetők.

A közösségi fejlesztések urbánus válfaja természetes módon célozza meg a meglévő városszövet hiátusait. Ezen belül gyakran olyan ingatlanokat is célba vesz, amelyek kis méretük vagy a beruházás bonyolultsága miatt - pl. meglévő épületek átalakítása, védett épületek stb. - a piaci ingatlanfejlesztést kevésbé vonzzák. Ilyen módon a kompakt város kialakításában hiánypótló résztvevővé válhat, mely a piaci szereplök által alacsony haszonnal fejleszthetőnek értékelt területeket vesz célba.

A fenntartható közlekedési rendszerek követelménye Jabareen szerint tartalmazza a közlekedési igényeket csökkentő városforma kialakítását, ami a kompaktság, sürüség és funkcionális vegyesség irányába mutat. A gyalogos távolságban lévő környezet funkcionális gazdagsága - kiemelve a gyermekintézmények és a mindennapi bevásárlás és szolgáltatások elérhetőségét - valósan csökkentheti a lakók napi megtett járműves utazásait. Nagyvárosi környezetben a választott úticélok, elsősorban a munkahely gyalogos elérhetősége nem jellemző, ezért a lakásvásárlók hely- 
választásában a különböző közlekedési rendszerek rendelkezésre állása, sürüsége, hatékonysága lehet fontos szempont. A piaci ingatlanfejlesztési gyakorlat ebben a tekintetben hủen tükrözi a vásárlói igényeket, és a lokáció értékelésében azt a közlekedési formát veszi tekintetbe, amelynek használata általános a lakók között. Csak azokban a nagyvárosokban válik szemponttá a fenntarthatónak tekinthető kerékpáros, illetve közösségi közlekedési módok elérhetösége, ahol ennek használata egyébként is jelentôs. Ezekben a városokban, ahol a közlekedési mód választása valós alternatívát jelent, a választott lokáció integráltsága a fenntartható közlekedési rendszerekbe a telek fenntarthatóságának legjobb, ráadásul könnyen számszerüsíthető jellemzője.

Az ökológiai irányultságú közösségek összetétele azt mutatja, hogy tagjaik között a városi átlag feletti a „puha” közlekedési módokat - kerékpárt, közösségi közlekedést - használók aránya. Ezért a városi co-housingok lokációs döntéseiben az ezt kiszolgáló hálózatok szerepe jóval magasabb, mint a piaci fejlesztéseknél.

Az optimális sürüség követelménye tervezési szempontból szorosan összefügg egyrészről a települési szolgáltatások gazdaságosságával, másrészről a gazdag társadalmi-gazdasági interakciók létrejöttével. Ugyanez a lakásvásárló számára igen szubjektív, az életformától és a saját habitustól, a személyes élettérrel kapcsolatos elvárásoktól függ. Európai városok elemzése azt mutatja, hogy az UN Habitat által számszerüsített minimum 150 fö/hektár sürüséget a hagyományos, legalább 4-5 szintes zártsorú városias beépítés tudja teljesíteni, vagy a szabadon álló, de legalább 8-10 szintes épülettömegekből álló telepszerü beépítések. A piaci ingatlanfejlesztőt a megtérülés optimalizálása az adott telek lehető legsủrübb beépítése felé hajtja, így a fenntartható beépítést az építési szabályok szigorúsága vagy engedékenysége szabja meg. A magas sürüségü lakókörnyezet objektív vagy szubjektív hátrányait pedig részben a már említett funkcionális és közlekedési előnyök, részben pedig a minőségi építészeti és várostervezés ellensúlyozhatja.

A városi építőközösségeket a piaci fejlesztéshez hasonlóan a sürủ beépítések felé hajtja az egy négyzetméter lakásra jutó telekár leszorításának igénye, hiszen nem tudják és nem is akarják megfizetni az alacsony, extenzív beépítésekhez szükséges zöldövezeti telkeket. Ugyanakkor a fejlesztésben jellemző, hogy a telken nagyobb és magasabb biológiai intenzitású, közösségi térként használt zöldfelületeket alakítanak ki, mint a piaci fejlesztők.

A vegyes területfelhasználás követelménye összvárosi szinten fogalmazódik meg a széles körben még ma is használatos modernista, funkciókat szétválasztó területhasználat-tervezés ellenében. A követelmény ma már nemcsak a településrendezésben érvényesül, de a nagyléptékủ városfejlesztési projektekben is, hiszen nemcsak vonzóbb, eladhatóbb városi környezetet hoz létre, de diverzifikálja az ingatlanfejlesztési terméket is, ellenállóbbá téve azt az ingatlanpiaci hullámvölgyekkel szemben. Számos város nemcsak nagy léptékben, de az épületek szintjén is előírja a vegyes funkciójú felhasználást: a belvárosban a lakások minimális arányát vagy a földszinteken helyi kereskedelmi-szolgáltató egységek kialakítását. Ennek ellenére a társasházat építő ingatlanfejlesztő és a lakásvásárló számára is a környezet gazdag funk- 
cionalitása mint az építési telek pozitív külső adottsága értelmezhető, amelyhez az épületben létrejövő más funkciók csak korlátozottan tehetnek hozzá. Vásárlói szinten ráadásul az egyéni stratégiák tovább színezhetik a képet, hiszen életkortól, életstílustól függően lehet döntő szerepe például a gyermekintézmények, egészségügyi vagy kulturális szolgáltatások, sportolási lehetőségek elérhetőségének, a munkahely vagy egy speciális gyermekintézmény közelsége pedig egyes esetekben minden egyéb szempontot felülírhat.

A városi co-housing közösségek egyrészt fokozottan keresik a változatos funkciójú környezetet, mert céljuk sokszor a külső kapcsolatrendszer gazdagítása is. Ugyanakkor számos esetben a fejlesztésen belül képesek létrehozni azt az - elsősorban közösségi, szociális, kulturális - funkciót, amely a szomszédságból hiányzik. Ezek miatt az igények miatt az építőközösségeket sokszor nem riasztják azok a szabályozások, amelyek például a földszinten nem lakás célú hasznosítást írnak elő, de a piac az üzlethelyiségek, irodák létrehozását nem támogatja.

$A$ diverzitás követelménye sokfajta városi minőséget foglalhat magába, lehetnek funkcionális, társadalmi, építészeti dimenziói is. A funkcionális változatosság követelményéről a vegyes területfelhasználást elemezve már szóltunk. Az építészeti változatosság követelménye lassanként teret nyerhet a piaci lakásépítéseknél, ahol az egyedi építészeti arculat, a vásárlók kívánságai szerint alakítható alaprajzok és belsőépítészet segít versenyben az individuális igényeket és ízlést kielégítő családi házzal szemben. Építészek és városépítészek feladata az egyedi arculatra törekvés mellett biztosítani az utcaképbe és városképbe illeszkedést. Nehezebb városi problémakört takar a társadalmi diverzitás fogalma. Bizonyos csoportok, mint például a különböző életszakaszban lévő háztartások, mozgáskorlátozottak, hallás- és látássérültek stb. együttélése egyre elfogadottabbá válik, és a piaci lakásfejlesztés is egyre gyakrabban reagál erre vegyes lakásméretek kialakításával, illetve a speciális szükségleteknek megfelelő kiépítéssel. Más, például vallási vagy etnikai kisebbségek integrációja az általános elöítéletek miatt nehezebb. A társasház fejlesztője számára a szomszédságban élő etnikai vagy vallási kisebbségek az értékesítésben korlátokat vagy speciális vevőkört jelentenek. A legsúlyosabb problémát azonban a társadalmi státusz szerinti szegregáció folyamatainak fékezése jelenti. Annak ellenére, hogy a gazdasági szegregáció egyértelműen rontja a város fenntarthatóságát, a piaci lakásfejlesztés pénzügyi logikája miatt természetszerüen növeli a szegregáció szintjét. Különösen súlyos ez azoknak a csoportoknak az esetében, akik önerőből nem is képesek megjelenni a lakáspiaci fejlesztésekben.

A co-housing mozgalom a kezdetekor jellemzően középosztályi jelenség volt, amit a szakirodalom gyakran kárhoztat. Az újdonság iránti nyitottság és az olcsó lokációk felé törekvés azonban sokszor azt eredményezte, hogy a közösségi épületek alacsonyabb státuszú területen jelentek meg - esetenként egy későbbi dzsentrifikáció elindítójaként. Ugyanakkor a co-housing mozgalom fejlődésével egyre gyakoribbá váltak az egy-egy kisebbség számára - pl. csak időseknek, nőknek szóló, vallási vagy szexuális irányultság alapján - szerveződő fejlesztések. Az ezredforduló után sok induló közösség továbbfejlesztette az integrációt, különböző státuszú lakók, illetve 
sokszor kiemelten hátrányos helyzetủ csoportok - fogyatékosok, állami gondozottak, volt hajléktalanok stb. - befogadásával.

A Passive Solar Design követelményét Jabareen városi, városrészi és épületléptékben is megvalósíthatónak és követendőnek ítéli. Ennek teljesítése teszi / tenné lehetővé, hogy épületeinket a helyi klímának megfelelően úgy tervezzük, hogy a fütés, hütés és a friss levegő biztosítása a lehető legkisebb bevitt energiával, passzív építészeti eszközökkel váljon lehetővé, ugyanakkor a környezetbarát energiatermelési módok számára is a lehető legjobb müszaki lehetőséget biztosítson épített környezetünk. Az európai történeti városok esetében azonban a történeti szövet útját állja a telepítés és az utcaszerkezet energetikai optimalizálásának. Nagy erőfeszítésekkel is csak közelíthetjük a beépítést a Passive Solar Design ideáljához, mint például a körülépített udvaros beépítés udvari szárnyainak bontásával. Csak városrésznyi új fejlesztések vagy rehabilitációk esetében formálható olyan új utca- és telekszerkezet, amely ezeket a követelményeket figyelembe veszi. Az egyteleknyi léptékü fejlesztések esetén a beépítés paramétereit jellemzően meghatározzák az építési elöírások, amelyek az energetikai és klimatikus szempontokat esztétikai, történeti, városképi, funkcionális szempontokkal próbálják egyesíteni. Mindezek ellenére a Passive Solar Design a telek geometriájának és az építési szabályoknak a segítségével a legkönynyebben számszerüsíthető és objektíven modellezhető a fenti fenntarthatósági követelmények közül. Ennek alapján az adott telek lehetőségei mint annak helyi energiája jellemezhető, az ebből megvalósított szint már az adott fejlesztés tudatosságának kérdése.

Ma még az ingatlanpiaci és a közösségi lakásépítés lokációs döntéseiben is alig játszik szerepet a telek benapozottsága, hiszen az energetikai minősítést az épületszerkezetek és a gépészet megválasztásával el lehet érni.

A Green Design követelménye Jaberdeen összefoglalója alapján a városi zöldfelületek növelését, rendszerbe szervezését, a még természetközeli területek beépítéstől való védelmét jelenti. Ehhez az értelmezéshez az utóbbi időben a városi mikro zöld elemek támogatása járult. A szakirodalom szerint a városi zöldterületek szomszédsága mérhetően emeli az ingatlanfejlesztés termékeinek, elsősorban a lakásoknak az értékét, így a piaci lakásfejlesztők számára a városi zöldfelület - park, folyópart, városi erdő stb. - közelsége a telek jelentős helyzeti energiáját jelenti. A telek helyi energiájaként értelmezhető, ha a geometria, a talajadottságok, a klíma és a hatályos építési szabályok alapján a beépítés mellett intenzív zöldfelület, kert kialakítására van lehetôség. Az adott telken belül viszont a beépítési lehetőségek maximális kihasználása és különösen a kötelező gépkocsibeállók elhelyezése sokszor ellentétbe kerül a zöld környezet, akárcsak a zöld mikroelemek telepítésének igényével.

A piaci fejlesztésekkel szemben a közösségi fejlesztések helyválasztásánál nagy súllyal esik latba nemcsak a telek környezetében lévő zöldfelület, de a telken lévő vagy kialakítható zöldfelület is. A közösség számára ez nemcsak beruházási költséget, hanem közösségi területet is jelent, ezért kiemelten fontos. Sok közösségi beruházásban megfigyelhető, hogy a közös zöldfelület kialakítását előtérbe helyezik a gépkocsiparkolókkal szemben is. 
2. táblázat. A piaci és a co-housing alapú városi lakásfejlesztésekben érvényesülő szempontok összevetése

\begin{tabular}{|c|c|c|}
\hline Fenntartható várostervezési elvek Jabareen szerint & Piaci fejlesztés & $\begin{array}{l}\text { Közösségi } \\
\text { fejlesztés }\end{array}$ \\
\hline a kompaktság & & \\
\hline a fenntartható közlekedési rendszerek & & \\
\hline a beépítés és a lakosság optimális sürüsége & & \\
\hline a vegyes területfelhasználás & & \\
\hline $\begin{array}{l}\text { diverzitás: a funkciók, tevékenységek, formák, társadalmi csoportok } \\
\text { változatossága }\end{array}$ & & \\
\hline $\begin{array}{l}\text { az éghajlati és benapozási viszonyok kihasználását lehetővé tévő } \\
\text { Passive Solar Design }\end{array}$ & & \\
\hline az élő környezet integrálását biztosító Green Design & & \\
\hline
\end{tabular}

Jelmagyarázat: nyilak iránya: melyik fejlesztésnél fontosabb az adott szempont (balra a piaci, jobbra a közösségi), nyilak árnyalata: a szempontok egymáshoz viszonyított fontosságát fejezi ki (világos - kevésbé fontos, sötét - nagyon fontos)

Az elemzések és összehasonlítások alapján a piaci, illetve co-housing alapú városi lakásfejlesztések helyválasztási preferenciáinak különbségét a következő táblázat szerint vethetjük össze (2. táblázat).

Elméletünk illusztrálására olyan városok megvalósult példáinak értékelése indokolt, ahol mind a közösségi együttlakás, mind a környezettudatos szemlélet a magyarnál lényegesen előrehaladottabb. A gyakorlati alkalmazás, a rendelkezésre álló adatok és a szakirodalmi feldolgozottság szempontjából Berlin egyértelmúen az egyik legjobban kutatható és elemzésre érdemes a nagyszámú megvalósult co-housing fejlesztésével. Az ezredforduló berlini építőközösségei direkt önkormányzati támogatás nélkül, piaci környezetben dolgoztak, így lokációs döntéseik várhatóan jól jellemzik a fejlesztői gondolkodástól való eltérést.

\section{BERLIN, AZ ÉPÍTŐKÖZÖSSÉGEK SZÍNTERE}

A berlini építőközösségek látványos elterjedését az új évezred elején a lakáspiac második világháború utáni változásai és az ezekhez a változásokhoz kapcsolódó szervezeti, finanszírozási, ingatlanjogi újítások alapozták meg. A lakáshiány enyhítésére 1952-től önkormányzati szociális lakásépítés vette kezdetét, ezzel párhuzamosan fokozatosan beindultak a beruházók lakófejlesztései is. 1968-ban elindult egy szervezett politikai „kommuna-mozgalom”, ami összefogta a közösségben lakó csoportokat, amelyek között a fiatalok lakásközösségei (németül: Wohngemeinschaft) és családos csoportok is akadtak, belső városrészekben és külső területeken egyaránt. ${ }^{21}$ Ezek a gyakran többgenerációs, kisléptékü együttélések a berlini építőközösségek öseinek is tekinthetőek. Az 1970-es évek végétől több városrészben elindult a lerom-

\footnotetext{
${ }^{21}$ Roedig 2008. 968-980.
} 
lott állapotú önkormányzati lakóingatlanok házfoglalása. Az illegális foglalásokat végrehajtó csoportok mottója szerint ,jobb illegálisan befoglalva megmenteni egy értékes épületet, mint egy befektetô által lebontani hagyni!"22

A 2000-es évek elejére a belső városrészek folyamatosan növekvő lakásárai megfizethetetlenné váltak a fiatalabb generációk számára, amit súlyosbított a 2008-as gazdasági válság. Ennek következtében elindultak a külső területeken fekvő, alacsonyabb árú, nagyméretü lakópark fejlesztések és kiköltözések. A berlini fiatalok egy része azonban a város belső területein kívánt maradni, a lakások árát pedig a fejlesztő cég kihagyásával leszorítani. ${ }^{23}$

Ez az úgynevezett építőközösség (németül: Baugruppe, Baugemeinschaft), melyben a jövőbeli lakástulajdonosok maguk a fejlesztők. A folyamat általában kétféleképpen lehetséges: vagy egy jogi személyiséggel bíró, a közösség tagjaiból álló szervezet (cég, szövetkezet, egyesület) vásárol üres területet és kivitelező céget bíz meg az építés lebonyolításával, vagy egy építész-fejlesztő iroda segíti a csoportot, a telek megvásárlásától az épület felépítéséig, a közösségfejlesztésen át. A hagyományos értelemben vett fejlesztő kihagyása miatt nem épül be a fejlesztő haszna és a hirdetési költség a végső lakásárba, a közösség megléte miatt végső eladáskor a hiányzó lakók toborzása önszerveződően történik. Ennek eredményeképp átlagosan 25\%-kal olcsóbbak Berlinben az építőközösségek által létrehozott lakóépületek.

Az építőközösségek számos középosztálybeli családnak tették lehetővé a lakástulajdont, mely a magas bérleti díjak és a csökkenő nyugdíj miatt egyre fontosabb biztonsági hálóként is szolgál. A lakástulajdon stabilitása mellett az építőközösségek többnyire magasabb lakásminőséget is biztosítanak. Míg a fejlesztők által létrehozott lakások egy átlagos felhasználót feltételeznek, addig az építöközösségek képesek speciálisabb igényeket meghatározni és beépíteni ezeket a tervezési folyamatba, melynek eredménye egy színvonalasabb, az egyéni igényeknek és ízlésnek megfelelö otthon lesz. ${ }^{24}$

\section{6. ÉPÍTÖKÖZÖSSÉGEK PANKOWBAN}

Az elemzésünk alapjául szolgáló adatbázis egész Berlin közösségi alapú fejlesztésü lakóépület projektjeit, összesen 304 darab megvalósult, építés vagy tervezés alatt álló ingatlant tartalmazza. A gyüjtés alapját a Co-housing Berlin gyüjtőoldalon ${ }^{25}$ található 234 épület képezte, amelyet a Miethauser Syndicat egyesület ${ }^{26} 17$ darab berlini épületével és a Self Made City címü könyv ${ }^{27}$ által összegyüjtött 119 darab ingatlannal vetettünk össze és egészítettük ki.

\footnotetext{
${ }^{22}$ Ruby-Ruby 2008.

${ }^{23}$ Ruby et al. 2007.

${ }^{24}$ Ruby-Janson 2014.

${ }^{25}$ CoHousing|Berlin, for Cooperative Building and Living website.

${ }^{26}$ Miethaeuser Syndikat weboldala.

${ }^{27}$ Ring-Eidner 2013. 28-46.
} 
Az adatbázisunkban szereplö épületek több mint egynegyede, pontosan 85 darab található Pankow kerületében. Elemzésünket a vizsgálandó épületek számossága és a kerület sokfélesége miatt koncentráljuk Pankow kerületre.

Pankow Berlin legnépesebb és második legnagyobb kerülete. A kerület a városközponttól a városhatárig terjed ki észak-keleti irányban, ennek megfelelően beépítés és városkép szempontjából vegyes. Egyaránt megtalálhatóak a sürün beépített területek és családi házas zöldövezetek, régi városrészek, újonnan fejlesztett területek és fejlesztés alatt állóak is, jól leképezve Berlin városszerkezeti változatosságát.

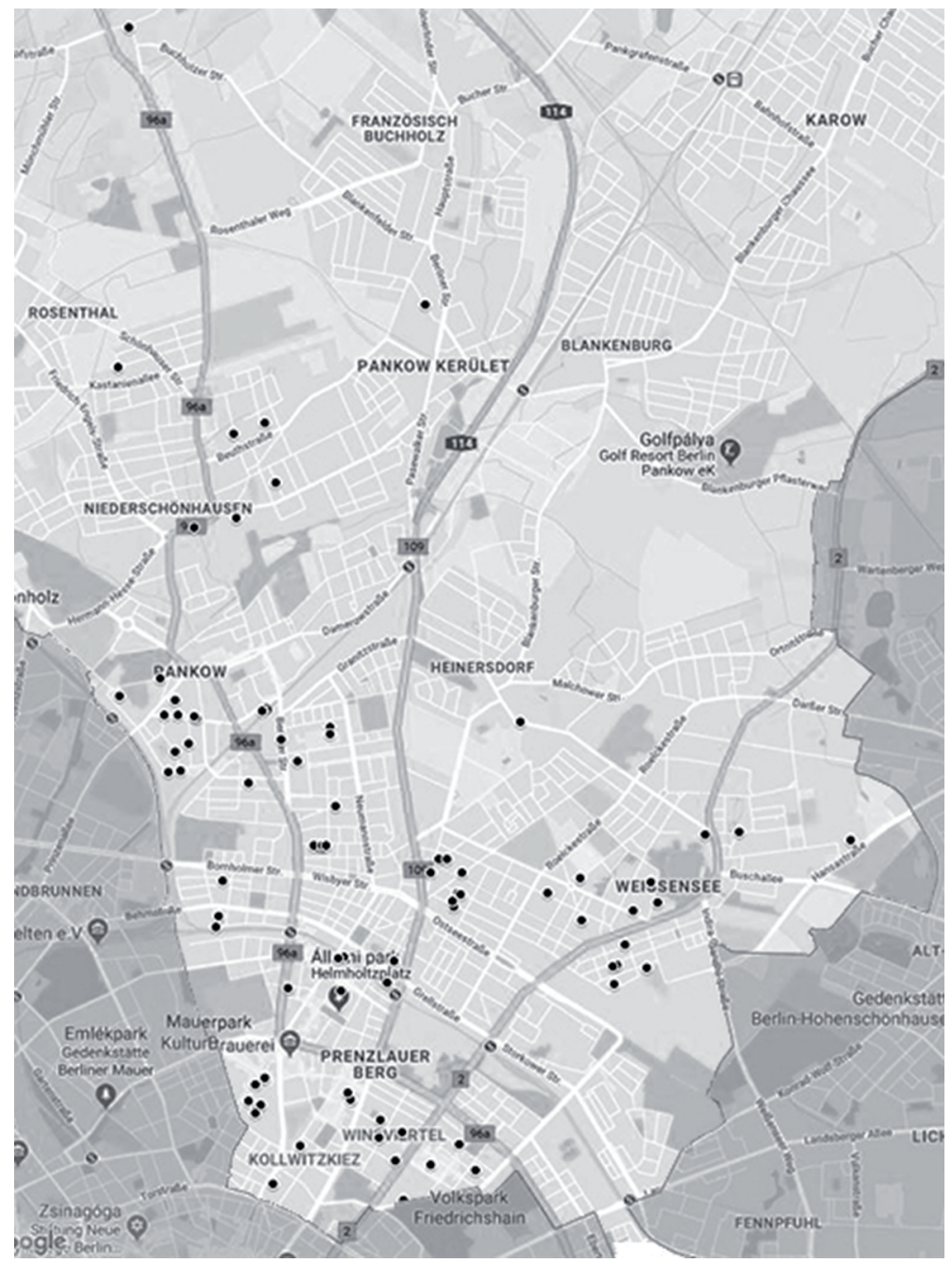

1. ábra. Térkép: a Pankow területen található közösségi fejlesztésű épületek kerületen belüli helyzete. Forrás: google earth alapján saját térkép 
A kerület 13 külön identitással rendelkező területi egységből áll, melyek közül Weissensee, Prenzlauer Berg és Old-Pankow területek találhatóak a városközponthoz (Mitte) legközelebb.

A pankowi projektek közül kettő meghiúsult, nyolc tervezési fázisban van, öt kivitelezés alatt áll, nyolcvan darab 2004-2019 között megvalósult és jelenleg is lakott. Vizsgálatunkban a megvalósult és kivitelezés alatt álló épületeket vettük figyelembe, amelyeknek elhelyezkedését az 1. ábra mutatja. A vizsgálat tárgyát képező közösségi alapú lakóépületek lakóegységeinek száma 5 és 45 közé esik, átlag 15 darab $(14,92)$.

A szakirodalom kiemeli, hogy az egyesítés után Berlin sürüsége alacsony volt, a város területén számos alulfejlesztett ingatlan, foghíj állt rendelkezésre ${ }^{28}$. Így nem csoda, hogy a vizsgált minta túlnyomó többsége, 74 lakóház új építésű, és csak 11 készült meglévő épület átalakításával vagy bővítésével. A konverzióval létrejött épületek aránya azonban még így is kiemelkedő a piaci fejlesztésekhez képest. A 85 vizsgált épületből 9 található nem városias környezetben, így elmondható, hogy a fejlesztések elsősorban Pankow történeti szövetének kiegészítéseként épültek ki, a kompakt város követelményeit támogatták.

A vizsgált épületeket gyüjtő térképen megfigyelhető, hogy a kerületben a közösségi fejlesztésú épületek darabszáma a városhoz közeledve nő, egy-egy közlekedési csomópontban sürüsödik. 76 közösségi épületre jellemző, hogy jól megközelíthető és sokféle funkcióval körülvett. Tehát megállapítható, hogy a helyválasztásnál általánosan fontos volt a jó megközelíthetöség követelménye és a sokfunckiójú, gazdag városi környezet is.

A vizsgált 85 épület közül csak 1 projekt található zöldövezetben, 10 darab alacsony intenzív vagy családiházas lakóövezetben, 27 darab kisvárosias környezetben, 47 darab pedig nagyvárosias területen, így a projektek több mint háromnegyede teljesíti a fenntartható városi sürüség követelményét is. 24 projekt zártsorú beépítésü, belső udvaros, többszintes épületekből álló tömbben helyezkedik el és annak megfelelően egészíti ki a beépítést, nagyvárosias területeken. A nagyvárosias és kisvárosias területeken egyaránt megtalálhatóak keretes beépítésbe (közös nagy belsőudvaros) illeszkedő projektek, melyekböl összesen 34 darabot gyüjtöttünk. A város folyamatos fejlesztései következtében a területen több vegyes beépítésủ tömb is található, közösségi fejlesztésủ épületből 10 található ilyen területen. 17 épület vagy épületegyüttes beépítése szabadonálló, ezek a példák a zöldmezős és a lakóövezetben, illetve 6 darab kisvárosias környezetben helyezkednek el. A konkrét telekválasztásnál jellemző egyrészt, hogy a közösségi fejlesztésü telkek mérete kisebb, illetve a rajta létrehozható lakásszám és a beépíthető négyzetméter alacsonyabb. Ez fakad egyrészt a közösség igényéből, vagyis hogy a 15 körüli lakásszámot tartják ideálisnak, másrészt pedig a befektetőknek ezen telekméreten nem lehetne akkora hasznuk (2. ábra).

A vizsgált épületek minimum egyharmadában (adatok hiányában 32 darab projektről tudjuk biztosan) jelen van a szociális fókusz: ezekben a házakban közös

\footnotetext{
${ }^{28}$ Krämer-Kuhn 2009.
} 
PANKOWI ÉPÍTÖKÖZÖSSÉGEK BEÉPÍTÉSI TÍPUSA

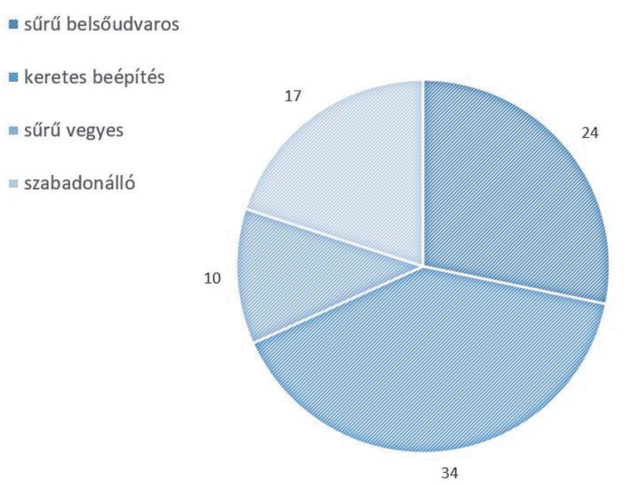

PANKOWI ÉPÍTŐKÖZÖSSÉGEK VÁROSI HELYZET

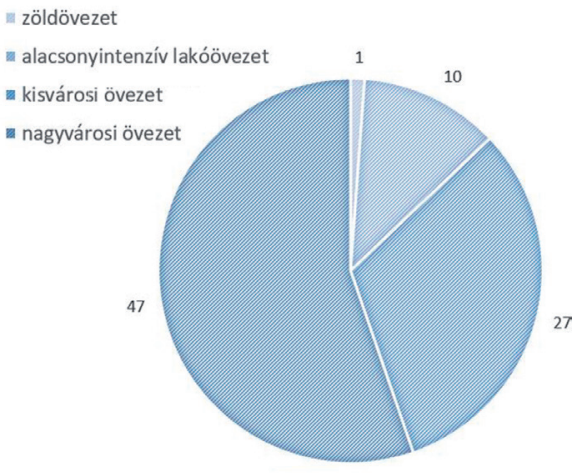

2. ábra. Pankow építőközösségeinek városszerkezeti helyzete és beépítési típusai. Forrás: saját szerkesztés

programokat szerveznek a lakóknak, melyekhez akár a környéken élők is csatlakozhatnak. A vizsgált projektek lakóinak összetétele korosztály és családi állapot szerint vegyes, egy részükben a csoport indulásakor kifejezett cél volt a heterogén közösség létrehozása. Általánosan elmondható, hogy a vagyoni helyzetük hasonló az egy épületben közösséget vállalóknak, de ennek ellenkezőjére is van példa: a Leuchtturm közösség ${ }^{29}$ a finanszírozási modellt úgy dolgozta ki, hogy az lehetővé tegye a lakások egyharmadába alacsonyabb jövedelmű családok költözését. ${ }^{30}$

A berlini közösségi fejlesztésủ épületekre jellemző a magas építészeti minőség, mely az adott telek ideális funkcionális elrendezésére és a helyszín nyújtotta adottságok kihasználására is vonatkozik. Az így kialakuló kompakt épülettömegeket gyakran új energetikai technológiákkal is kombinálják. A co-housing lakóközösségekröl általánosan is elmondható, hogy a környezeti fenntarthatóságot egyik céljuknak tüzik ki, mely a participáció révén már a tervezés első fázisában beépül. ${ }^{31}$

A Pankow kerületben vizsgált épület mindegyike rendelkezik közös kerttel, több ingatlannál tetőteraszon és tetőkerten is osztozik a közösség. A projektek egy részéröl tudjuk, hogy a közösségi kertet ideiglenesen vagy állandóan megnyitják a környéken élők számára. Az ilyen kertek találkozási pontokként müködnek, melyek fejlesztik a lakók közötti interakciót és a városi kultúrát, melyből az egész szomszédság profitál. ${ }^{32}$

\footnotetext{
${ }^{29}$ Leuchtturm közösség weboldala.

${ }^{30}$ Ring-Eidner 2013. 210-214.

${ }^{31}$ Ring-Eidner 2013. 217-218.

${ }^{32}$ Ring-Eidner 2013. 216.
} 
Összességében így Pankow közösségi fejlesztésű lakóépületeiről az a képünk alakul ki, hogy építtetőik sokkal inkább szem előtt tartották a fenntartható városi környezet Jabareen-féle kritériumait, mint az átlagos piaci lakásfejlesztések.

\section{AZ ÖNKORMÁNYZATOK SZEREPE}

Vizsgálatainkból kitünik, hogy bár a közösségi lakásépítés nemcsak tervezési, fejlesztési és fenntartási döntéseiben, de már a lokáció választásakor is a piaci projekteknél jobban törekszik a fenntarthatóság szempontjainak érvényesítésére, törekvéseiket azonban erősen behatárolja az ingatlanpiaci környezet. Így a fenntarthatósági elönyök érvényesítéséhez sokban segít az építőközösségek önkormányzati vagy állami támogatása.

A közösségi lakhatás megépült példáiban a városszerkezeti helyzet szinte minden válfajára találunk példát. Az 1990-es évek közepétől megvalósult nemzetközi városi közösségi lakásfejlesztések helyválasztása részben a helykeresésben részt vevő lakók igényei, részben az aktuális ingatlanpiaci folyamatok, részben pedig a helyi önkormányzat városfejlesztési céljainak eredőjében jött létre. Azokban a településekben, ahol az önkormányzat nem, vagy csak informálisan segítette a lakásközösségeket, mint ahogy erre Berlin legtöbb építőközössége példa, az épületek jórészt azokon a foghíjtelkeken valósultak meg, amelyek az építőközösségek tagjai számára elérhetöek voltak a piacon. Azokban a városokban azonban, ahol a városvezetés felismerte az építőközösségek szerepét a városfejlesztési folyamatokban, és ezért aktív telek- és ingatlanpolitikával segítette azok létrejöttét, az épületek elhelyezkedése tükrözi a városfejlesztési stratégiák térszerkezeti fókuszait, legyen ez a belváros rehabilitációja, mint Lipcsében, új városrészek fejlesztése, mint Bécsben és Freiburgban, vagy ipari területek átalakulásának katalizálása, mint Bécsben vagy Zürichben. ${ }^{33} \mathrm{~A}$ co-housing közösségek fejlesztési döntései így nemcsak az épület léptékében, de városszerkezeti léptékben is tudják segíteni a település fenntartható fejlődését.

A co-housing közösségek telekválasztásának kritikus szempontja a tervezett lakásegységek száma. A tisztán magánerőre támaszkodó fejlesztések jellemzően kisebb lakásszámra (10-25 lakásra) törekednek, mert így látják biztosítottnak a lakások feltöltését közelebbi, baráti, ismerősi körből, a közösségi szempontok fellazítása nélkül. Ezek a fejlesztések olyan foghíjakat keresnek, amelyek 1000-2000 négyzetméter hasznos felület beépítésére nyújtanak lehetőséget. Jellemző az egy-két fogatba szervezett, 4-5 szintes épület, a környezettől függően akár zártsorú, akár szabadonálló beépítésben. Ilyen a pankowi példáink többsége.

A megépült példák egy másik csoportja igen nagy, akár 100-hoz közelítő lakásszámmal valósult meg, elsősorban ott, ahol a fejlesztést a város vezetésével együttmüködve, sokszor támogatott vagy részben támogatott lakásokkal tervezték. Ez a nagyságrend felel meg egy-egy funkciót váltó épület, például volt iskola vagy gyárépület

\footnotetext{
${ }^{33}$ Szabó-Babos 2019. 56-65.
} 
alapterületének, mint például a Sargfabrik (Bécs) ${ }^{34}$ vagy a Forum Kreuzberg (Berlin) ${ }^{35}$ esetében. Illetve az új városfejlesztési területeken kialakított szabályozások is a legtöbb esetben ilyen nagyságrendủ épületeket tesznek lehetővé, amire példa lehet Berlin Pankow kerületében az 5 épületből álló, ütemezetten megvalósított Quartier Vineta ${ }^{36}$ vagy a jelenleg is fejlesztés alatt álló Quartier Heyn ${ }^{37}$ projekt. Az építőközösségek sok esetben olyan „,problémás” telkek fejlesztésében is lehetőséget látnak, amelyekre az ingatlanfejlesztői piacon nincs, vagy bizonytalan a kereslet. İgy a co-housing fejlesztés pilot projektjévé válhat akár leromlott városnegyed megújításának, akár volt ipari terület konverziójának, akár új városfejlesztési területnek. A lakóközösség így nemcsak a projekt megvalósításában, de már a participatív várostervezési folyamatokban, később pedig a környék átalakulásában, társadalmi kohéziójának megteremtésében is fontos és szilárd partnerévé válhat az önkormányzatnak.

\section{8. ÖSSZEFOGLALÁS}

A nemzetközi szakirodalom, a megépült példák esettanulmányai, illetve Pankow co-housing projektjeinek összehasonlító elemzése alapján egyértelmű számunkra, hogy a co-housing mozgalom közösségi fejlesztései piaci körülmények között is közelebb visznek a fenntartható város célkitüzéséhez, mint a piaci alapú lakóházfejlesztések. Ezek a közösségek a fejlesztési telek választásakor nagyobb súllyal veszik figyelembe azokat a helyi és helyzeti energiákat, amelyek a projekt fenntarthatóságát segítik, ugyanakkor a fejlesztés folyamán is törekednek a környezetkímélő technológiák alkalmazására. Bár a legtöbb szakértő egyetért abban, hogy a közösségi lakásformák sohasem válthatják ki a városi lakásállományban a vállalkozói lakásépítést, illetve az állami és önkormányzati finanszírozásban létrehozott szociális bérlakásállományt, speciális szerepük még alacsony arányuk mellett is fontos, mint a városfejlesztési folyamatok katalizátorai, technológiai és társadalmi újítások kísérleti terepe.

Mindezek alapján a települési önkormányzat számára hasznos lehet, ha eszközeivel támogatja a létrejövő közösségi lakásfejlesztést. Ezek az eszközök lehetnek általánosak is, mint a speciális információszolgáltatás, a jogi segítségnyújtás, a rugalmas szabályozás - például gépkocsi-elhelyezés tekintetében -, az adókedvezmény vagy hitelkezesség. A térspecifikus városfejlesztési célokat azonban csak akkor tudják elősegíteni a lakóközösségek, ha az önkormányzat célzott és differenciált telek- és ingatlanpolitikával segíti őket.

Magyarországon a co-housing fejlesztések útjába számos ingatlanpiaci, jogi, finanszírozási akadály áll, így nem csoda, hogy a létező közösségek többnyire kis léptékben, bizonytalan jogi konstrukcióban szerveződnek és helyüket egy-egy meglévő nagyobb családi ház vagy sorház átalakításával találják meg. Az ingatlanpiac e

\footnotetext{
${ }^{34}$ Sargfabrik co-housing weboldala.

${ }^{35}$ Forum Kreuzberg co-housing weboldala.

${ }^{36}$ Ring-Eidner 2013. 39-40.

${ }^{37}$ Ring-Eidner 2013. 41-42.
} 
speciális szektorának szükössége miatt a helyválasztásban is csak gyengén érvényesülhetnek fenntarthatósági szempontjaik, a tulajdonviszonyok miatt pedig fejlesztési döntéseikben is csak részlegesen tudják érvényesíteni azokat. A helyzet megváltozására csak akkor számíthatunk, ha a városfejlesztés felkent szereplői, az önkormányzatok is felismerik, hogy a lakásfejlesztő közösségek nemcsak lakáspolitikájukhoz, társadalomfejlesztési céljaikhoz, de a városszövet átalakításához, a fenntarthatósági célok eléréséhez is hathatós partnerek lehetnek.

\section{IRODALOM}

A New Strategy of Sustainable Neighbourhood Planning. Five principles. http://mirror.unhabitat.org/ pmss/listItemDetails.aspx?publicationID=3518 (Utolsó megtekintés: 2019. 05. 02.)

Babos Annamária - Horogh Petra - K. Theisler Katalin: Co-housing. Példák Bécsben és a közösségi együttélés lehetőségei Budapesten. Utóirat. A Régi-Új Magyar Épitőmüvészet melléklete 18 (2018) 101. 69-76.

Chan, Winnie Yuen-Pik: The Phenomenon of Building Groups (Baugruppe) in Berlin: What Changes when a Community Starts Building? Diplomadolgozat. Dessau Institute of Architecture 2010. ISSUU Publisher. https://issuu.com/winnie/docs/thesis_book/27 (Utolsó megtekintés: 2019. 05. 09.)

Christian, Diana Leafe: Creating a Life together, Practical Tools to Grow Ecovillages and Intentional Communities. New Society Publishers, Gabriola Islands 2016.

CoHousing|Berlin - for Cooperative Building and Living. website. http://www.cohousing-berlin.de/en (Utolsó megtekintés: 2019. 05. 02.)

Forum Kreuzberg weboldala. https://forumkreuzberg.de/ (Utolsó megtekintés: 2019. 05. 03.)

Jabareen, Yosef: Sustainable Urban Form. Journal of Planning Education and Research 26 (2006) $38-52$.

Khoshnaw, Rebaz - Kissfazekas, Kornélia: Urban Form and Sustainability in Historic Cities. A Case Study of Two Neighbourhoods in Erbil City, Iraq. Épités - Épitészettudomány 47 (2019) 1-2. 189-215; https://akademiai.com/doi/abs/10.1556/096.2018.014 (Utolsó megtekintés: 2019. 05. 31.)

Krämer, Stefan - Kuhn, Gerd: Städte und Baugemeinschaften. Wüstenrot Stiftung (Hg.) Karl Krämer Verlag, Stuttgart+Zürich 2009.

Marckmann, Bella Margrethe Mørch - Gram-Hanssen, Kirsten - Christensen, Toke Haunstrup: Sustainable Living and Co-Housing. Evidence from a Case Study of Eco-Villages. Built Environment 38 (2012) 3.

Meltzer, Graham: Sustainable Community. Learning from the Co-housing Model. Trafford Publishing, Victoria (BC) 2005.

Miethaeuser Syndikat website. https://www.syndikat.org/en/ (Utolsó megtekintés: 2019. 05. 02.)

New Urban Agenda for the EU. European Commission website. https://ec.europa.eu/futurium/en/ urban-agenda (Utolsó megtekintés: 2019. 05. 05.)

Report of the United Nations Conference on Environment and Development. Rio de Janeiro, 3-14 June 1992. United Nations website. http://www.un.org/documents/ga/conf151/aconf15126-1annex1.htm (Utolsó megtekintés: 2019. 05. 05.)

Report of the World Commission on Environment and Development. Our Common Future. Oslo, 20 March 1987. Ministry of Mines and Petroleum. http://mom.gov.af/Content/files/Bruntland_Report. pdf (Utolsó megtekintés: 2019. 05. 05.)

Resolution adopted by the General Assembly on 27 July 2012 - 66/288. - The future we want. Sustainable Development Platform. https://sustainabledevelopment.un.org/futurewewant.html (Utolsó megtekintés: 2019. 05. 05.) 
Ring, Kristien: Urban Living. Strategies for the Future. JOVIS, Berlin 2015.

Ring, Kristien - Eidner, Franziska: Berlin. Self-Initiated Urban Living and Architectural Interventions. JOVIS, Berlin 2013. 28-46.

Roedig, Schop: Housing for a building group in Berlin. Detail - Review of Architecture 48 (2008) 968-980.

Ruby, Andreas - Janson, Nathalie: Andreas Ruby and Nathalie Janson on the Baugruppe Initiative. Design Curial (2014) http://www.designcurial.com/ (Utolsó megtekintés: 2019. 05. 05.)

Ruby, Andreas - Ruby, Ilka: Urban transformation. Ruby Press, Berlin 2008.

Ruby, Andreas - Ruby, Ilka - Kries, Mateo - Mathias Müller, Daniel: Together! The New Architecture of the Collective. Vitra Design Museum, Weil am Rhein 2007.

Sargfabrik co-housing weboldala. https://www.sargfabrik.at/ (Utolsó megtekintés: 2019. 05. 08.)

Szabó Árpád: A városok fenntarthatóságának egyes szempontjai. In: Élhető Települési Táj. Településépitészeti Tanulmányok. Szerk.: Körmendy Imre. Budapesti Corvinus Egyetem, Budapest 2012. 91-105.

Szabó Julianna: A települési fenntarthatóság mérése. In: Budapest 2050: a belvárosi tömbök fennmaradásának esélyei. Szerk.: Alföldi György. TERC Kereskedelmi és Szolgáltató Kft., Budapest 2012. 92-107.

Szabó Julianna - Babos Annamária: Co-housing: Kortárs városias közösségi lakóházak innovatív építészeti megoldásai. Utóirat. A Régi-Új Magyar Építőmüvészet melléklete 19 (2019) 103. 56-65.

The new urban agenda of United Nations Conference on Housing and Sustainable Urban Development. In Quito, Ecuador, on 20 October 2016. Habitat III website. http://habitat3.org/the-new-urbanagenda/ (Utolsó megtekintés: 2019. 05. 05.)

Tummers, Lidewij: The re-emergence of self-managed co-housing in Europe: A critical review of co-housing research. TU Delft, Delft 2016.

Tummers, Lidewij: Learning from co-housing initiatives - Between Passivhaus engineers and active inhabitants. TU Delft, Delft 2017. 204-244.

Urban Agenda for the EU Pact of Amsterdam - 2016. European Commission website. https://ec.europa. eu/futurium/en/content/pact-amsterdam (Utolsó megtekintés: 2019. 05. 05.)

Walljasper, Jay: The Great Neighborhood Book. A Do-it-Yourself Guide to Placemaking. Project for Public Spaces, 2007.

Zulliger, Jürg: Wohnen morgen - Standortbestimmung und Perspektiven des gemeinnützigen Wohnungsbaus. Schweizerischer Verband für Wohnungswesen, Zürich 2007.

\title{
CO-HOUSING AND URBAN SUSTAINABILITY
}

\section{SITE SELECTIONS FOR MULTI-APARTMENT BUILDINGS OF REAL ESTATEMENT DEVELOPERS AND CO-HOUSING COMMUNITIES IN THE LIGHT OF URBAN SUSTAINABILITY}

\begin{abstract}
Summary
Since the 1990s, aspects of sustainability and of community housing have been widespread in urban development in Western Europe. These are converging trends, as many co-housing communities see sustainable lifestyle as their basic value, while building an integrated housing community and the associated social benefits can be seen as the third social pillar of sustainability. However, in some development decisions, point of views of the two trends are not always the same. In our article we are looking for the answer to the question of how the choice of location of urban multi-dwelling residential properties can be influenced by the environmentally conscious and co-housing aspects, whether the differences between the two viewpoints can be identified.
\end{abstract}


Our analysis is based on Yosef Jabareen's urban sustainability criteria. By analogy with a location theory in urban geography, we introduce the concept of local and situational energy of the site. We set parallels between Jabareen's criteria and location aspects of real estate development, contrasting the viewpoint of typical market real estate development with those of community housing. Our studies are based on the findings and case studies of the co-housing literature, and - lacking relevant Hungarian experience -, a database of community homes built in Berlin. Finally, we raise the issue of urban responsibility in the orientation of community housing development, in support of their sustainable localization decisions.

Keywords: sustainability, urban housing, co-housing, building communities, location, local and positional energy

Open Access nyilatkozat: A cikk a Creative Commons Attribution 4.0 International License (https://creativecommons.org/licenses/by/4.0) feltételei szerint publikált Open Access közlemény, melynek szellemében a cikk bármilyen médiumban szabadon felhasználható, megosztható és újraközölhető, feltéve, hogy az eredeti szerző és a közlés helye, illetve a CC License linkje és az esetlegesen végrehajtott módosítások feltüntetésre kerülnek. (SID_1)

Beérkezett: 2019. május 24. Elfogadva: 2019. június 26. 
